\section{目次 (I)}

1. まえがき。2. 犬の骼炎に刘するマッキンタイアの 分類. 3. 神経型ジステンパーとシュロットハウアーの 症候諭. 4. ジステンパー病変飞甜け当緝胞封入体の問 题. 5. ジステンパーに上る䀝の炎症について。

\section{1 ま え ま゙}

臨床家にとつて, 犬のジステンパーは柾めて普通の疾 病であり，関心の樑いるのが女るに拘らず，その痕理に

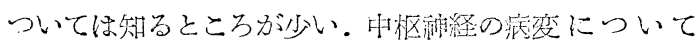

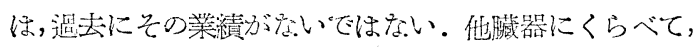
むしろ, 光の病理組織学的研究は, 中枢神経の䌞索に限

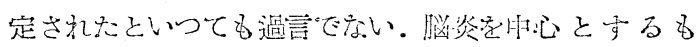

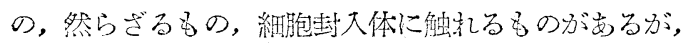

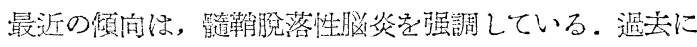

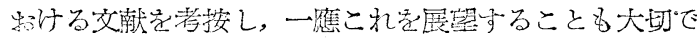
あろう。

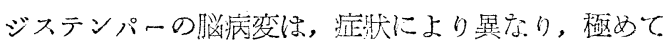
多㨾性であることは，榙学者のひとしく㲘めているとこ

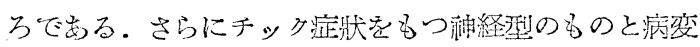
との関倸など学解くのは，今日のとこ万難間題といわね

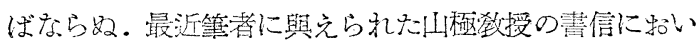

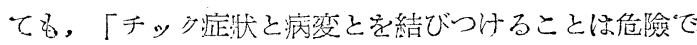

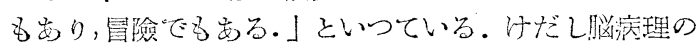
大家としては，爱当なる忠言であらう。

しかし，これ程悉でに榣床家にとつて電要な疾病が，

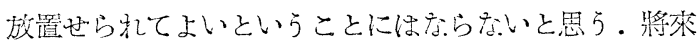
の研究に資寸るといら意味に执いて，最近息で約 40 年の 研究淮步を文献によつて紹介したいの゙でする。

\section{2 犬の脳炎に対するマッキン タイアの分類}

マッキンタイア(MOINTYRE) ら23)38)の分類に上る

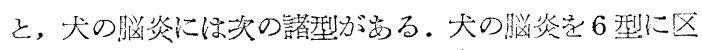

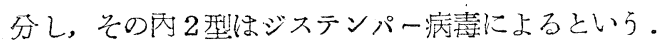

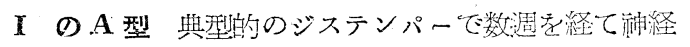

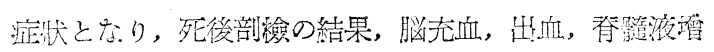

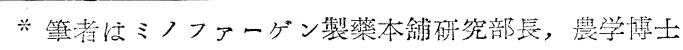
医学搏士.

(本諭交の要旨拄昭利25年10月28日查京大学農学部で開

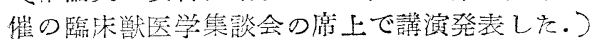

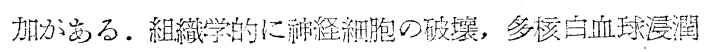
に上る間買性肺炎が㟧る。

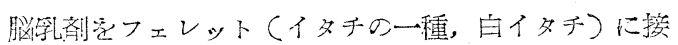

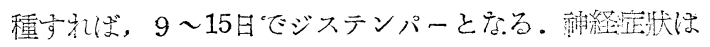
物とらく二次性中毒或は敗血症による。

$\mathbf{I} の \mathbf{B}$ 型 レードロー・ダンキンのウィールスとは

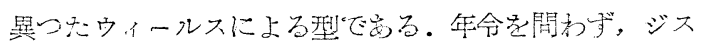

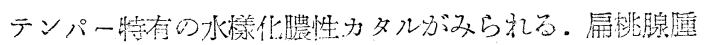

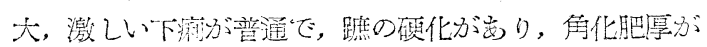
澈しい，并の他肺充血，激しい十二指腸炎，脾，䀒の随

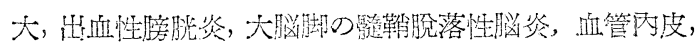

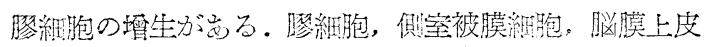

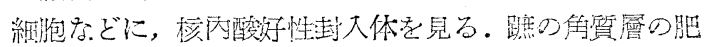
厚が甚しい。(注.從來余り臨床家に観察されていない) 蹠, 脳, 肺, 牌の乳剂定フェレットに接種すると, 17〜

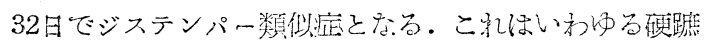
症 (H.ARD PAD DISEASE, 以下 HPD と略) として, 最近 知られるにいた゚た。

II型 これはIのB型に似ているが,フェレッ下に文

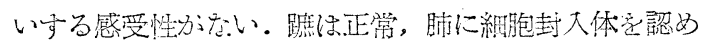
な⿻.

III 型呼吸器蚂上び一般症状をく、脳㷋犁で岕る。 犬物よびフェレットに感染しない。

IIII 型 原虫前に上る脳炎型で，トキソプラズマ性 のものぶある。

V 型 猚多九原因によるらので, 栄養不是, 中毒, 寄 生虫性のるのがある。

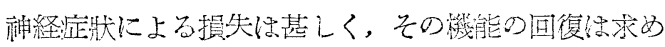
られない。脳定狀を示ずシステンパーはその栠疫血清を 用いても無價徝である。IE型の脳湴狀を見るものは，

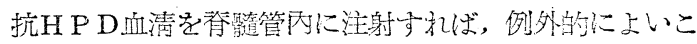

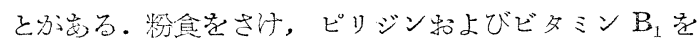

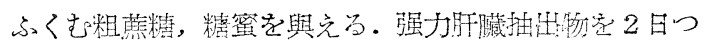

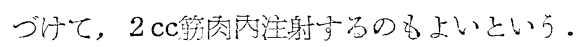

**従来 Neggedia Canis (Sintagaglia), Engephiditozo.t (Kantorowicz, Leny), Enogprabimozoon (M.avoveLIAN) がジステンパーの病原体として考元ら

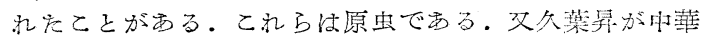
で発見した犬のトリパフゾーマ症の脳で激しい腅炎病変

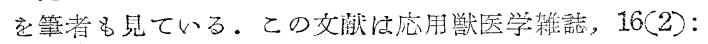

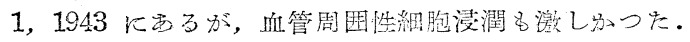




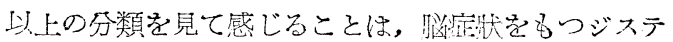

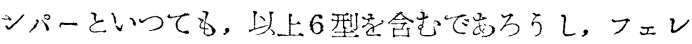
ットによるウィールス努離堂しない限り，純稡な型を取 り扱うことは容易でない。

從來ジステンパー性脳炎を誩断しているものの内に, この上うな注意力沱られていたとは，いにくいので要 る.ジステンパー脳淀狀の多稂性老語る前に, 犬の脳炎 の諸型を分類し，I型以外の榙脳炎を除いて診断するこ とがのぞましい.さらにジステンパー類似泟でせる硕蹨 宿の研究が，本邦でも必要でなかららか。或は最沂カプ ロフスキー（KOPROWSKI）に上る一元的なウィールスに

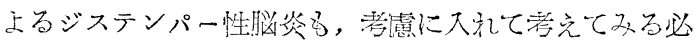
琴が岁る。本邦にみるいわゆる蝴経型ジステンパーの脳

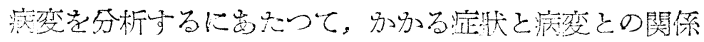
䛱，研究聞題と乙て雪要性を埣すと思われる。

\section{3 神経型ジステンパーと シニロットハウアーの症候部}

ジステンパーの脳病変については後退するごとく、い ろいろの研究があるが，臨床病理学の兒抑から考察した

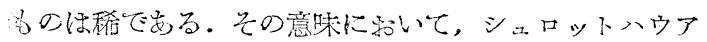

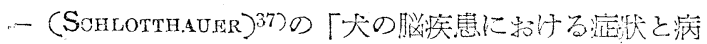

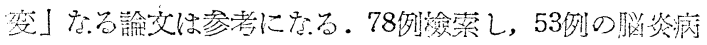

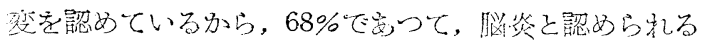

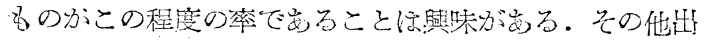

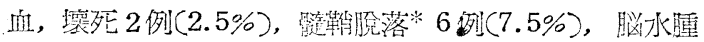
14例(18\%)老見ている。

病变として脳炎と訬断した53例の內訳は，リンパ球性

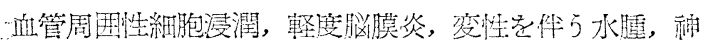
経細胞の破燷が44例（その內播種性30例，限局性14例)， リンパ球性細胞浸潤它欠いた播㣫性袖経細胞变性（完全

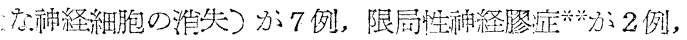
小脸灰白質にむる限局性小病変 1例である。

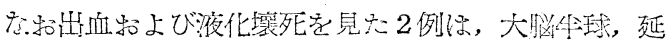
膸，脳橋に見ているし，脳水尰14例中4例は偏僛性に，

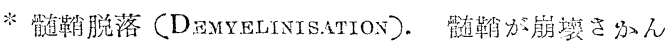

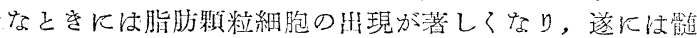

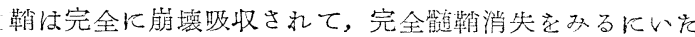

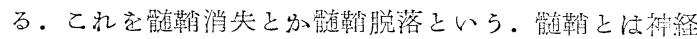

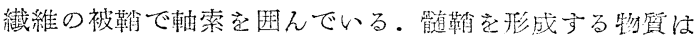

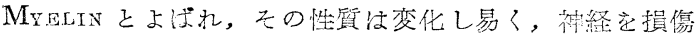

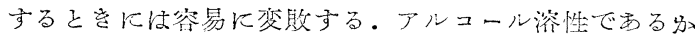

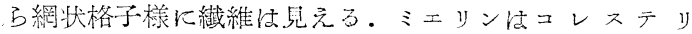
ン,レシチンなどのリポイドと脂肧っケラチンから成り 立つ。

养神経膠症 (GLIOSIS) は膠貿症又はグリア症とも いら。神経細胞の变性破壤より生じ艺組䋨の欠損部に膠

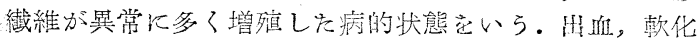

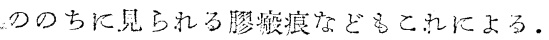

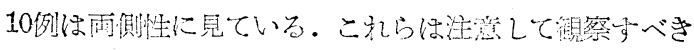
臨床病理学的所見で傢万弓。

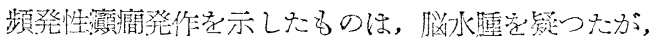

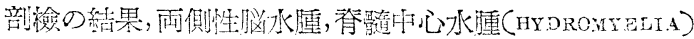

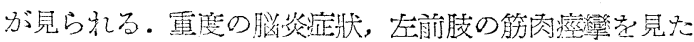

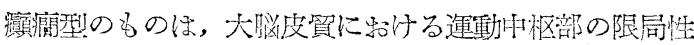

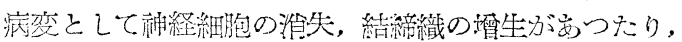

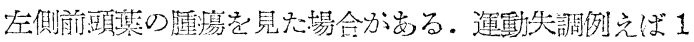
乃至擞保の筋群の慢性㽷變が岁る場令は通常ジステンパ 一後遗脳炎 (POST-DISTEMPER ENCEPHALITIS) でせる。 このときには大脳の一部に病㤎が限局している。播種性 脳炎の一般正状は持続步行, 门運動, 不自然先步行で出 るが，病変としては大这の破燷病变を示している。

小脳に限局与る脳焱型としては，遑動失調 (ATAXIA)

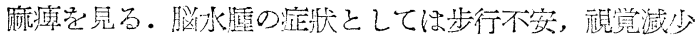

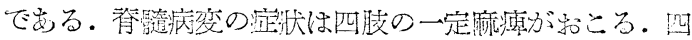

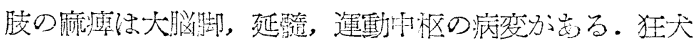

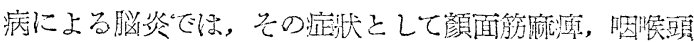

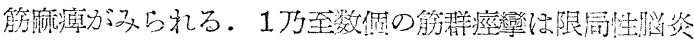
にかからた動物に久る最る普通の淀候で良る。

こ礼はしばしばジステンパーの際に発し，一般に舞踏

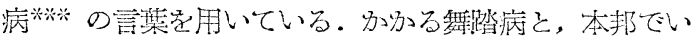

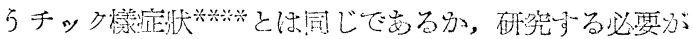
好万。

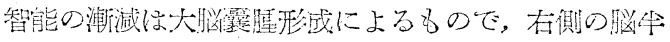

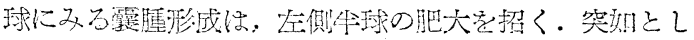

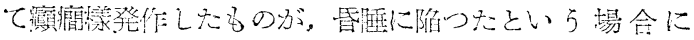

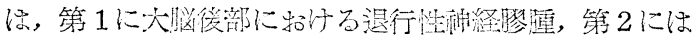

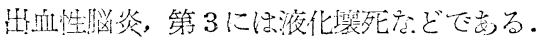

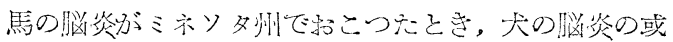

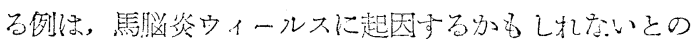
推測案行つている。

シュロットハウアーのとくジステンパー後遺忹脳炎

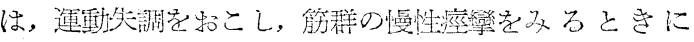

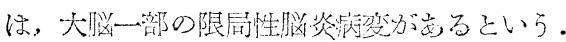

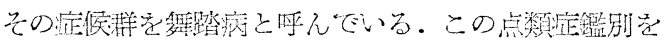

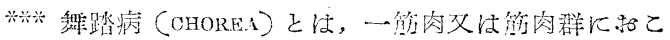

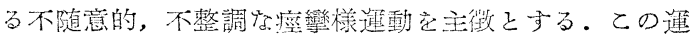
動は精神感㖶によつて甚しくなり，唾眠叫は静止する。

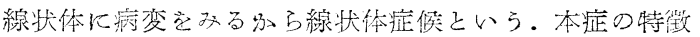

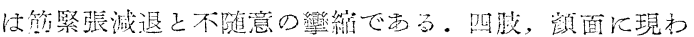

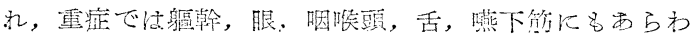

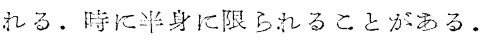

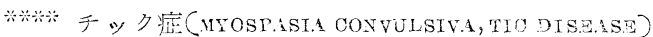
とは, 筇群例えば舌, 㸶喉, 溦面, 四脖, 身區幹の諸筑が

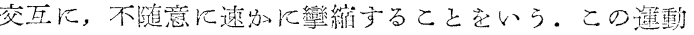

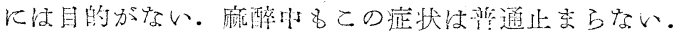

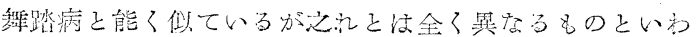
れている。 
詳しく行い,いろい弓の犬脳炎圭䛦䉼することがのぞま Lい.

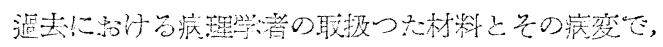

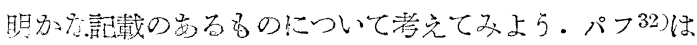
００例の烣服型ジステンパーの致死的なるのもしらベ，小

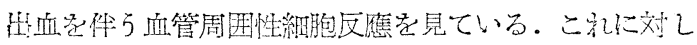
ドゥモンブルン4)(批制しているが，人の脳炎に似たも ので, フェレッ下感染隍性の点から, ジステンパーでな

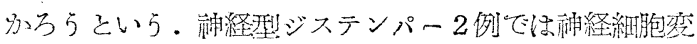

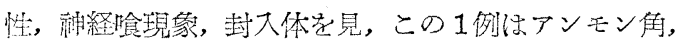

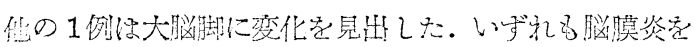

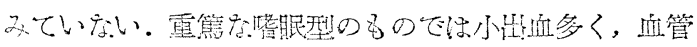

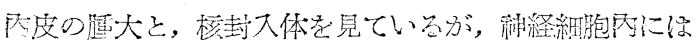
惠大体学見ていない。彼によると，ジステンパー・ウィ

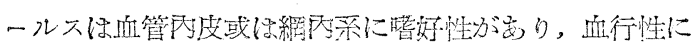

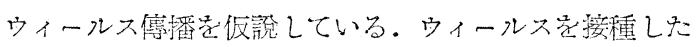

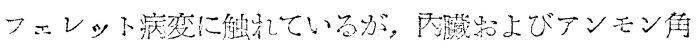

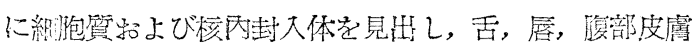

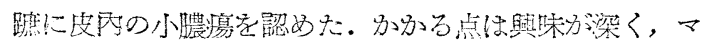

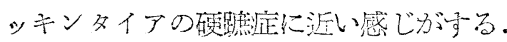

最沃カプロフスキー17)21)(狂犬病予防接種による䀎息

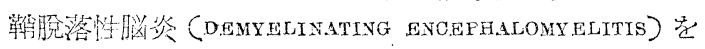

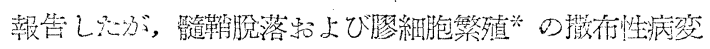
はアレンギー性機轉によつて和こること定発表したっつ ついて同じよらな病変がジステンパー性监炎と関連して 影こること老のべている。

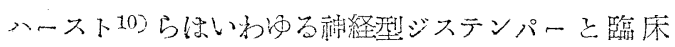
家のい5大の眇焱の痕原体としてジステンパー・ウィー

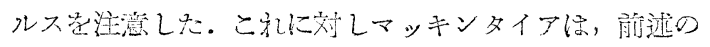
奶く、ジステンパー・ウィールスでは，等に神経細胞の

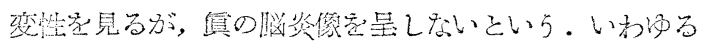
每経型ジステンパーには，ちがつたウィールスとして，

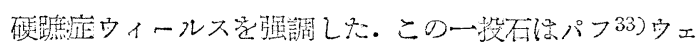
ルシュ43)などの砸究定よんでが，フルリンデ422の「やや

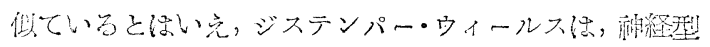
ジステンパー病原体であるジステンパー・ウィールス $\mathrm{B}$

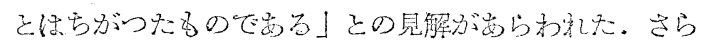
に剈経型ジステンパーは, 與型的な゙ステンパー・ウィー

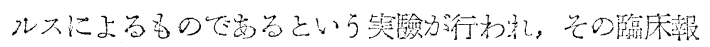

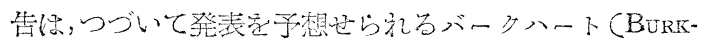
HART), ポッペンシーク (POPPENAIE) の未登表のりに

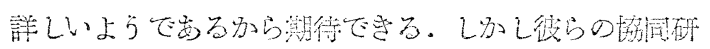

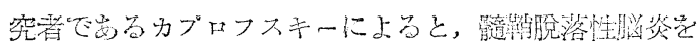

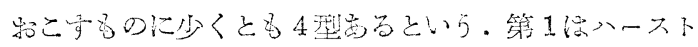
(1943), カプロフスキー（1950）によるジステンパー ・ウィールス，第2はフルリンデ（1948）に上るジステ

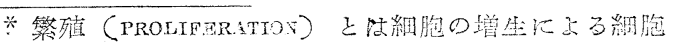
の増多す当痕変壳いう。
ンパー・ウィールス B 琹，第 3 にはジステンパー・ウ ィールスに斯るに毒性因子，第4にはマッキンタィア

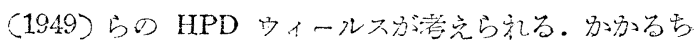

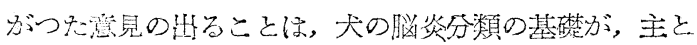
して噘格寺ぎる一今日では推獎されない月枢神経系痕 変に紀名礼ているから㔚こるるいいている。

要之, 神経型ジステンパーの確なる病変と症狀との関

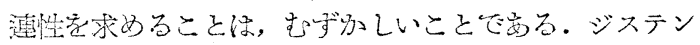

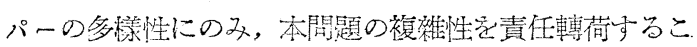
となく, 深刻に再出発さる必要があろう.ウィールス学,

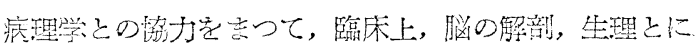

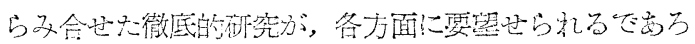

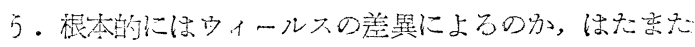

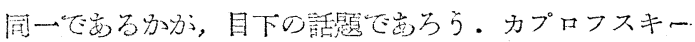

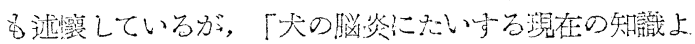
りすると，ジステンパーと硬蹠昰とのりィルース関係は

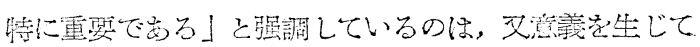
くる.

\section{4 ジステンパー病変における 細胞封入体 ${ }^{* *}$ の問題}

ジステンパーの緗胞封入体は，フニアブラザーズ7にに よつて，先の性格分不定だとせられている。最㳠ショれ テ40)方28例の偶発性:ジステンパー犬をしらべ，その90\%

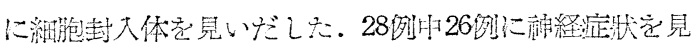

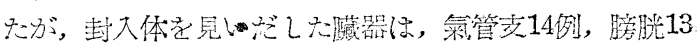
例, 胆管12例, 肺藏11例，㲚孟 8 例, 脾 8 例, 晹間膜口 ンパ暞8例で击つた.12例のアモン角に封入体老たと， W5

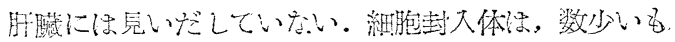

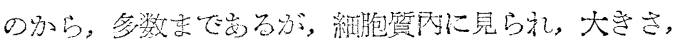

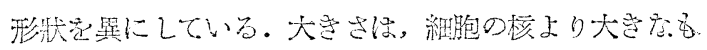
の济子。

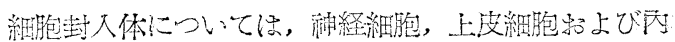

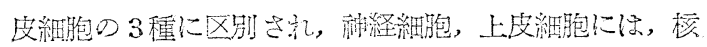

**細胞封入体 (OELL INCLUSION). ウィールス病では。 細狍封入体を导つものボ多々，例えば狂犬病のネグリ小

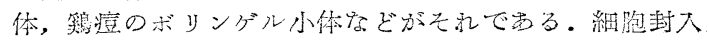

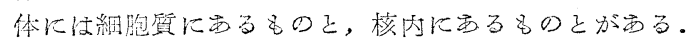
円形，棈円形の酸好性の小体である。小体ではボリンゲ ル小体, ガルニエリー小体の如く, ウィールスそのもの で沓子考元られるむのと，ネグリ小体の㚼く，細胞变

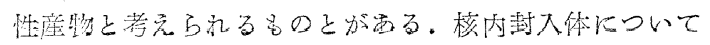

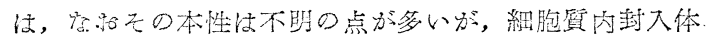

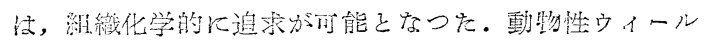

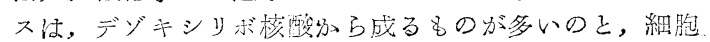

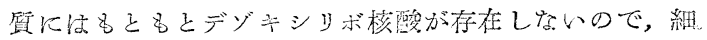

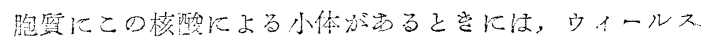
の存在を予想し得るといら程度に発起した。 
內封入体と細胞質內封入体とが報告されている。 ジステンパーで細胞封入体を初めて見いだしたる。は

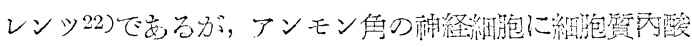

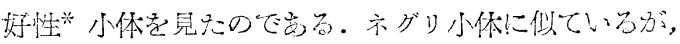

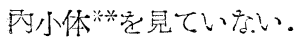

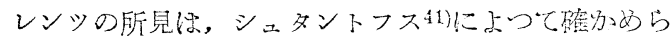

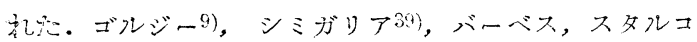

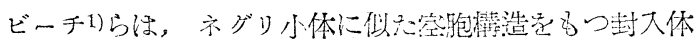
を神経細胞・プルキンエ細胞の細胞賢に認め犬。

サンフェリーチェ3ラ ( 7 例しらベ, 神経細胞, 䑁粘

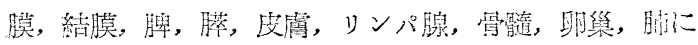

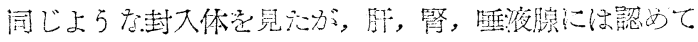
いな⿰.

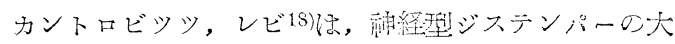

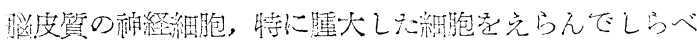

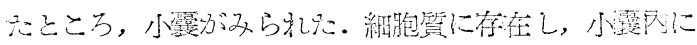

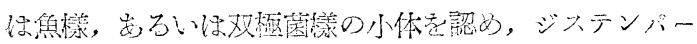

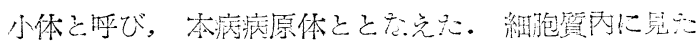
ものは一種の原虫性等生虫で，爱の脳に2る Encepha litozoon cuniculi に似ているといら一說安提供したの

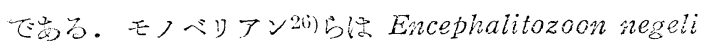
と命名している结か，パードロー29，ペテルス改び山然

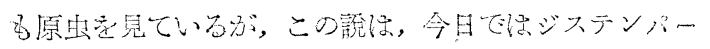

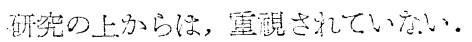

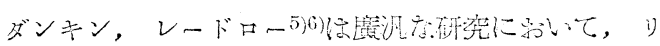

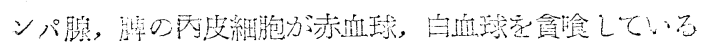

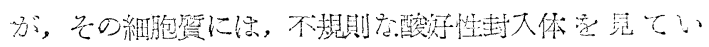

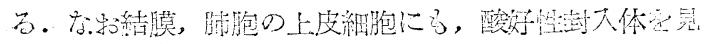
穴.

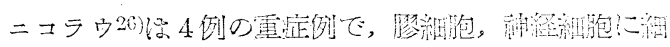

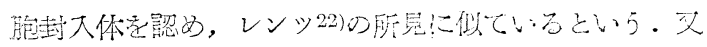

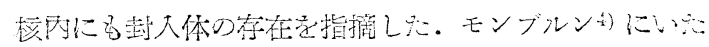

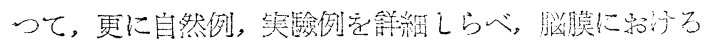

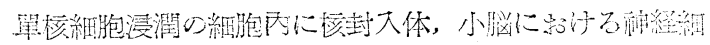

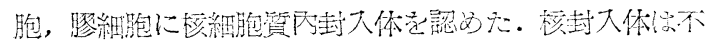

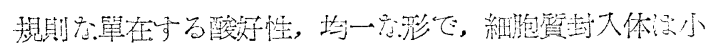

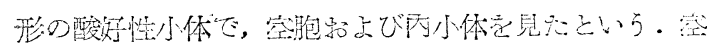

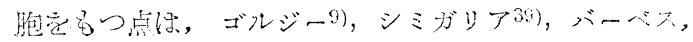

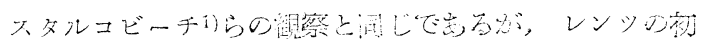

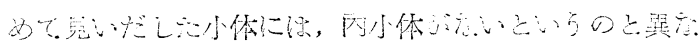

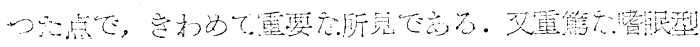

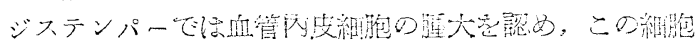

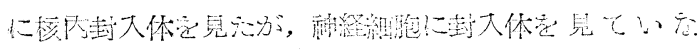

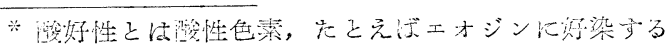
ことをいう.

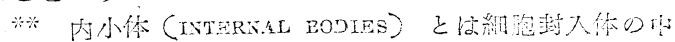

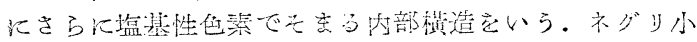

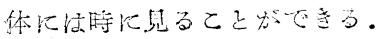

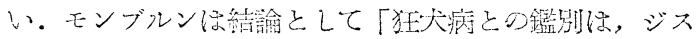

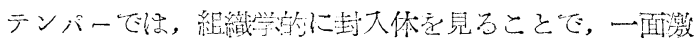

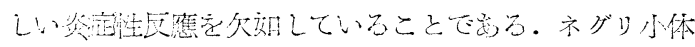

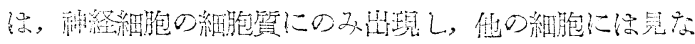

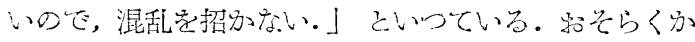
かることる屯万弓が，必ずしも特黑的とい充い。核封 大体家上く観察し，肝，氧管支，胃底腺，晹腺，胆管な

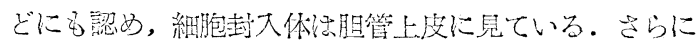
アンモン角に函詁よび細胞資封大体定夕天。

シュロットハウアー37)にしてる，犬の脳炎53例考行類 しているが，封大体 2 例定钼察し心。1例では，脳側室

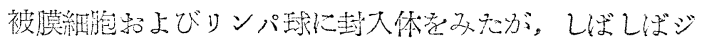
ステンパーに2ら虬る封大体に似ている。他の1例は，

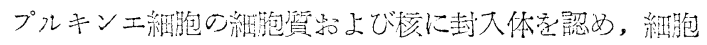

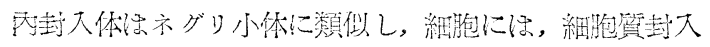

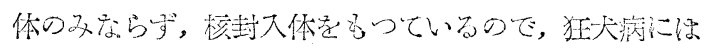
見ら礼ない所見でせるという。

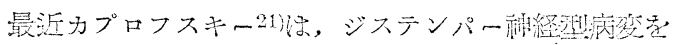

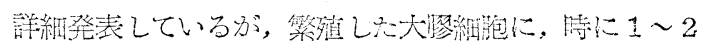

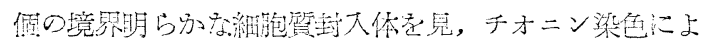

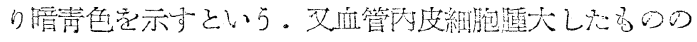
核岕に封大作定見大。

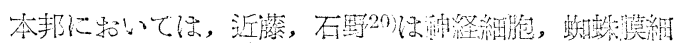

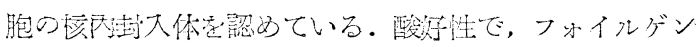

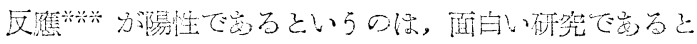

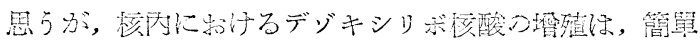

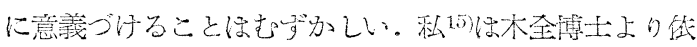

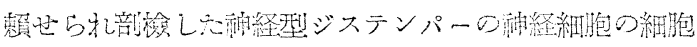

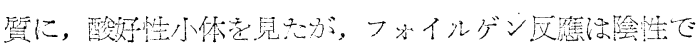
岕心然.

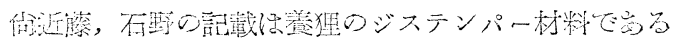

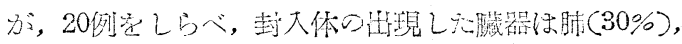

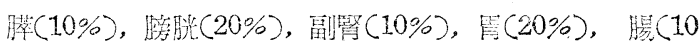

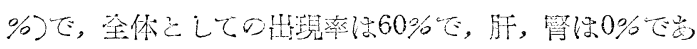
る.この率はショルテの研究90\%にくらべると低いが，

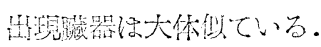

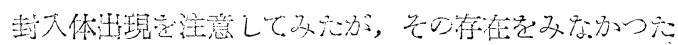

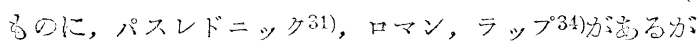

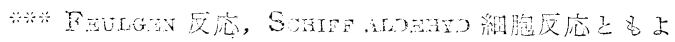

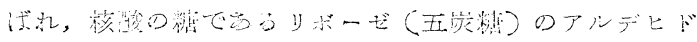

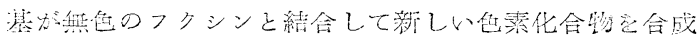

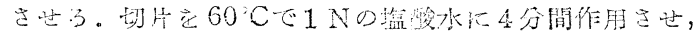

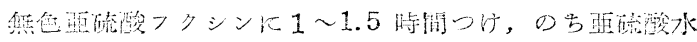

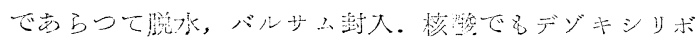

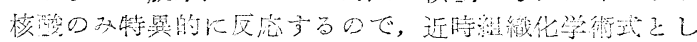

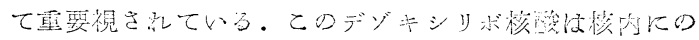

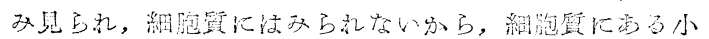

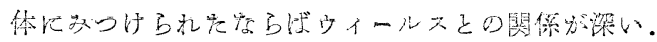




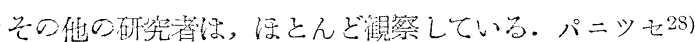
は艺の著家畜德染症学に彩いて，「病原体としてNegria canis (SiNAG.AGLI.1), ncephalitozoa (KANTOROWICZ, Lerry), Encephalitozoa (MarovediAy) な.どが命名

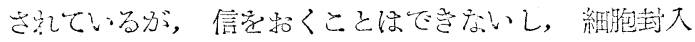
体马，狂犬病亦グリ小体の特徽的なるのに比すべくるな

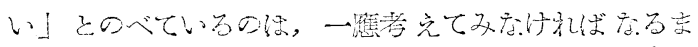
い.

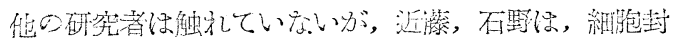

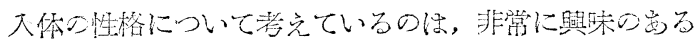

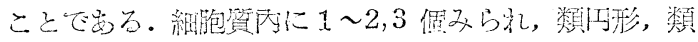

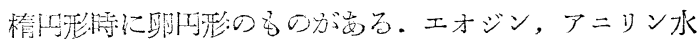
酸フクシン，石笼酸ブンテアナ紫，オランゲGに酸好性 に㳔染せら尔る、ベストカルミンに淡染，オキシダーゼ 区碓に淡青色光輝体として見光, ビクトリア青 4 R., = グロシン黑,フォイルゲン反應，脂肪染色，いずれも陰

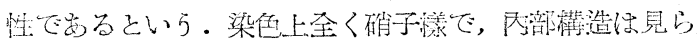
れない。ミトコンドリア染色でミミコンドリアは全く

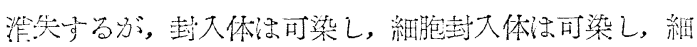

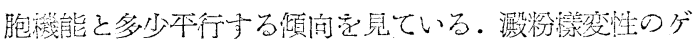
ンチアナ紫反應，コード反應を試久心が，いず扎陰性 である。

これらのことから，細胞筫に和ける蛋白筫性の顆程で

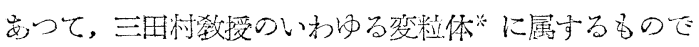

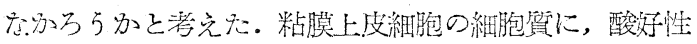
封入体を多るが，細胞の作つた顆粒であると思わ礼，就 中諭交中引用した。リュールス (LuHRs, 1926)，和篓。 (1937) の二次的產物に近い考光方とい光る。

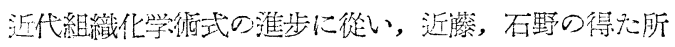

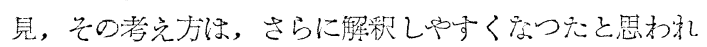

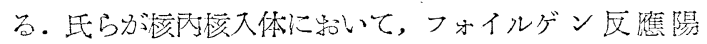

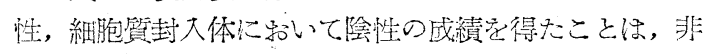
常に與味のあることである. 更にカプロフスキーダ新絟 細胞の細胞質內にチオニン・メタ少ロマジア反應陽性定 得ていることる，見のぶしてはならない。

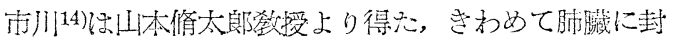
大体を多く見る材料について，号の組織化学的稳浩家発 表している。こ机によると，チォニンによる核酸メタク

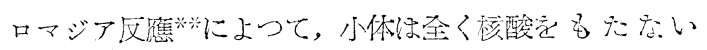

\footnotetext{
并变粒体 (メタコンドリア). 三田村教授に上つて等 づけられたタので, 系粘体(ミトコンドリア)から変化

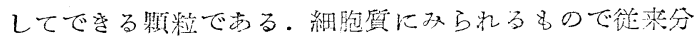

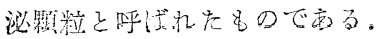

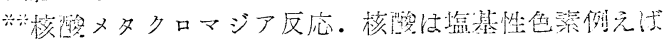

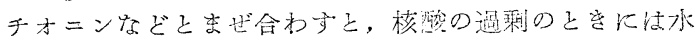

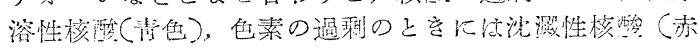

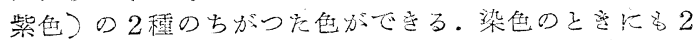
種の染志り方がみられる。このことをメタクロマジア上

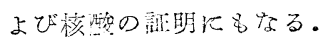

が，小休つ宗わりに核酸が多いブラァッ下 (BRACHET) のピロニン・メチル綠染色による核酸反應をしらべる と, チオニンによるメタクロマジア完見たところは，と゚

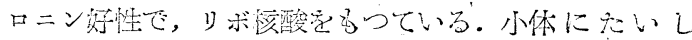
て，フォイルゲン核酸反磼定試又ると，細胞筫にあるほ

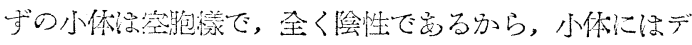

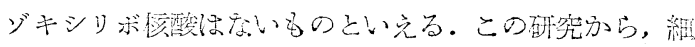

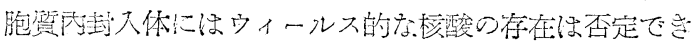

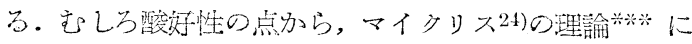

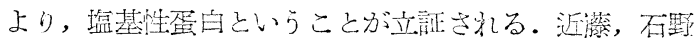

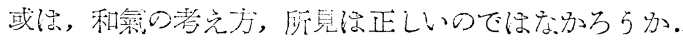

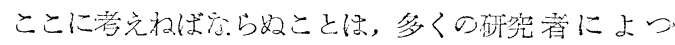

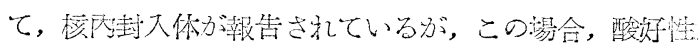

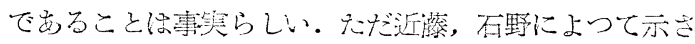

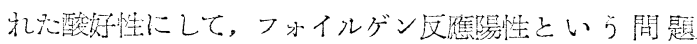

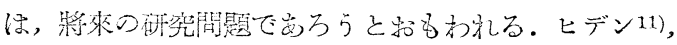
南川12)13引によつて，袖経好性りィールスによる核》仁

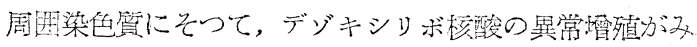

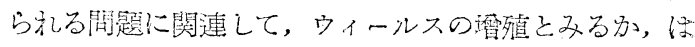

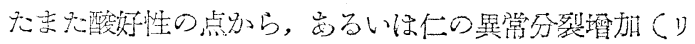
ボ桎酸つがあるのかもしれない。しかしフォイルゲン民

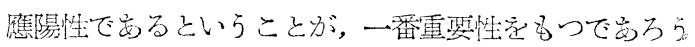
と思わ礼，今後の研究にまつものが多い。

\section{5 ジステンパーによる脳の 炎症について}

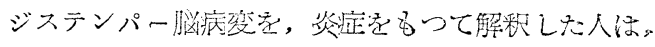
パニッセ2S)の退行性春簿炎(MYELITE DEGENERATIVE) 别

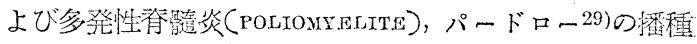
性脳炎 (Dissemir.tTad ENOEPH.ALItIS), ロマン, ラップ

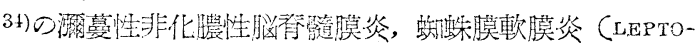
M.SNIGIT1S), ダンキン，レードロー5)6の非化膿性脳炎, マリネスコ2H)の湠蒙性, 变性的, 资症性脳炎, ペテルス, 山際のジステンパー性脳炎 (ST.AUP:-ENoRPH.ALITIS) カ プロフスキー21)の膸践脫落性脳炎 (DEMYELINATING ENC.eph.ALomyentis)，パスレドニック31)の桷蔓性非化膿性

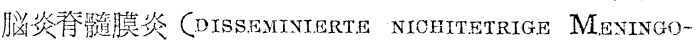

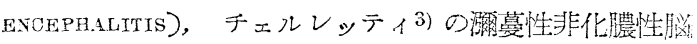

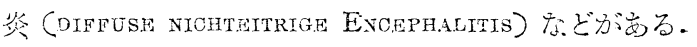
多くの人々は，脳炎は肯定しているが，その特徽を表現

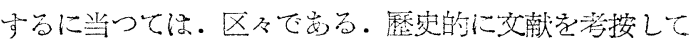
夕上万。

※** MrOHAELIS の理諭・メチレン䧳, ブリラント,ク レシール毒, チォニンなどの塩基性色素は陽性街電を示

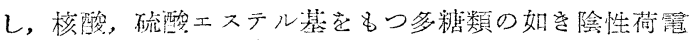

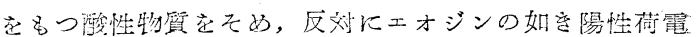

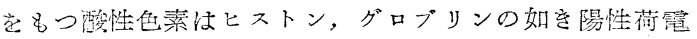

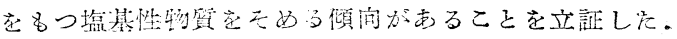


チェルレッテイは，为多ル型ジステンパーで蜼竾，

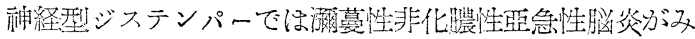
られる。後者では，血管周国性細胞浸潤，血管を胀心

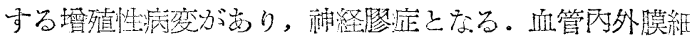
胞方溫形成し肥大寸るといらが，いずれにしてる增殖性 変化の强いことは，重要な所見であろら．ダンキン、レ

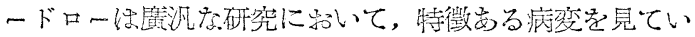
ないぶ, 非化膿性脳炎の存在起認めている。ロマンらは

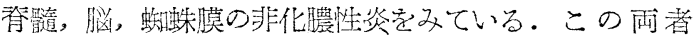
は，とるに細胞內に封入体をみていない。パスレドニッ ク蛙血管周囲性りンパ球性細胞浸潤，膠結節，出血，神

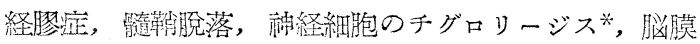

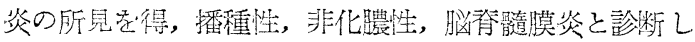
ている・パードローは桷暮性脳炎といりているが, 脳,

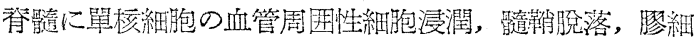
胞結節浮どがある・マリネスコの濔蔓性変性的脳炎なる るの结，血管周囲性りンパ球細胞浸潤，神経細胞変性が 强い。ペテルス，山際はジステンパー性脳炎をしらべ， 炎症性変化として血管周囲性にリンパ球，形筫細胞浸 潤, 血管墰殖, 沴細胞結節を久ている。乙かし必発性の 所見でなく，重要所見でないという。むしろ笪生虫性原 虫に上る炎症性反萑に上る病变形成について注目してい

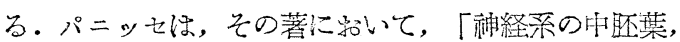

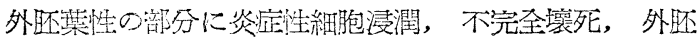

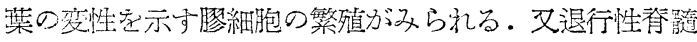

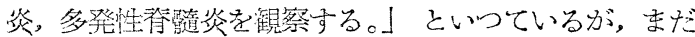
核心堂つい感じがしない。

このときにあたつて，カプロフスキーの髄䩴脫落性脳 炎は，きわめて明確詳細であるので，次項に勒いて紹介 Lたい.ジャービス(JERVIS), バークハート(BURKHART), カプロフスキー (1949) は, 狂犬病予防注射による犬の

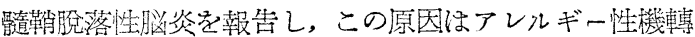
によるものでせろうと思われるる噵鞘脱落, 膠細胞結節繁 殖像の播種性病変定特徽とすることに言及した。 又この ことによつて，犬の脳炎の1型を明らかにしたのであ る。今回カプロフスキー,ジャービス,ジェームズ, バ ークハート, ポッペンシーク(1950) は, 他の1型とし ての犬脳炎のべ,こ秃はジステンパー性脳炎として從 來討議吧ら玑た幾多の間題にる関連して適切なるのであ ろうと，胃頭所感そのべている。

犬のジステンパー脳病变について织，既にのベたよう に, チェルレッティ, カントロどッッ, ガリェーゴ8)，マ リネスコ，ペテルス，山際などが，大心に研究した。

*チグロリージス。神経細胞の細胞筫は塩基性色素に そまるニッスル小体，すなわちリボ核淂が虎斑状儿存在 する。神経細胞の変性の結果, この虎斑溶解して, y ボ核酸消失の現象があるが，てれをチグロリージスとい 弓.
ンネス16)招よびシェーレル36)にいたつて，次のように指 摘している。

「脳炎経過と関係するジステンパー・ウィールスの結論

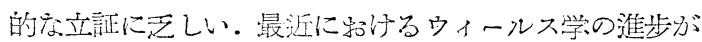
菨しいのに拘らず, ジステンパーと脳炎の閪題はジレン マに宿り，低然として未決定の間題定残している」と。 ハースト (HURST) 新よびその協力者 (1943) は，いわ ゆる新経型ジステンパーと臨床獸医家がとなえる，明ら 名な大脳炎の1型としての病原体として有名なジステン パー・ウィールスに注意を向けた。これにないしマッキ ンタイア括よびその謿力者 (1948) は，「ジステンパー

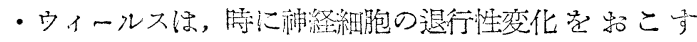
が，真の脳炎像定表わさない。いわ功る神経型ジステン パーは，光机とは別のウィールス，すなわち，HPD ウ イールスによつて特こる」といら．フルリンデス(1948) の意見では，「やや似ているが，ジステンパー新経型の 病原体は, ジステンパー・ウィールスB型であつて，ち がうものだ」といらのである。

かかる㒛說粉等の㭙期には, ウィールスの分離, フ二

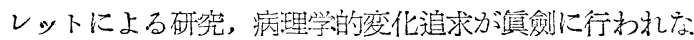
い限り, 單なる臨床嘼医家の分類は根抛少く, 從つて病

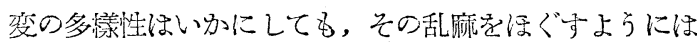
行かないであろう，その意味に徏いて，カプロフスキー によるウィールス分離確策な材料に物いて行つた病理学 研究は，今後の研究方向党示与と同特に，上き対象で㐫 ると思う。 (决号に続く)

\section{牛のミイラ胎兒}

ジェルシー種 2 才の若雌牛, 1944年12月22日に交配の 上受胎し，柆年 9 月に分婏ずべきるのが分婏せず，同年 12月オ八イオ州デラウェアのデューバー博士の䛦断によ りミミイラ胎兒が出ることがわからた。スティルベスト ロールを3回注射したが効杲がなく，箻者の䛦療所に來 た. 当時ノルウェーのオスロー獸医科大学のフラトゥラ 博士が來訪币で，同氏らが本症に眀胞ホルモン「フォリ クレン」の5万單位定注射後, 柆日ピトシン 5 10ccを 一部筋肉內, 一部皮下に注射し, 良い成績老得ていると いらので，光礼試文た。すなわち2月13日エストロト

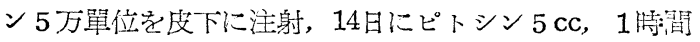

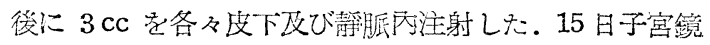

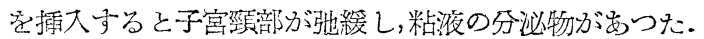

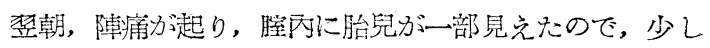
手先で助力すると, 長さ18インテのミイラ胎兒を分娩し た. 雌牛は元氣になり，21日退院した。與味あることに は、スティルベストロールを注射する前にはへルニアが

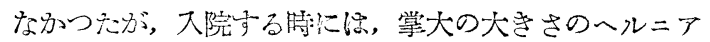
分岁つた. (紊藤) GuAR, W. F.: J.A. V. M. A., 108, 322 (1946). 